\title{
STATUTORY INTERPRETATION, LEGISLATIVE INACTION, AND CIVIL RIGHTS
}

\author{
Daniel A. Farber*
}

\begin{abstract}
On April 25, 1988, the Supreme Court ordered reargument in Patterson v. McLean Credit Union. ${ }^{1}$ Such routine procedural orders do not ordinarily receive widespread public attention unless a case is already in the limelight. Patterson was a seemingly routine case, in which the major issue was whether racially motivated harassment of an employee is actionable under a Reconstruction-era statute, 42 U.S.C. section $1981 .^{2}$ Not an insignificant question, surely, but also not a headline grabber. And yet, the Court's reargument order received front-page treatment and greatly alarmed many civil rights activists. ${ }^{3}$ The reason for all this attention was that the order did more than set the case for reargument. It also directed the parties to address an issue no one had previously raised in the case: whether to overrule Runyon v. McCrary, ${ }^{4}$ which held that section 1981 prohibits discrimi-
\end{abstract}

* Henry J. Fletcher Professor of Law, University of Minnesota. - Ed. I would like to thank Doug Baird, Bill Eskridge, Dianne Farber, Phil Frickey, Hank Greely, Richard Posner, David Shapiro, Suzanna Sherry, and Steve Yeazell for their helpful comments on earlier drafts.

1. 108 S. Ct. 1419 (1988).

2. The relevant statutory language provides that "[a]ll persons ... shall have the same right ... to make and enforce contracts ... as is enjoyed by white citizens ...." The court of appeals held that racial harassment is not cognizable under $\$ 1981$. Patterson v. McLean Credit Union, 805 F.2d 1143, 1145 (4th Cir. 1986).

3. For example, the decision was the leading story in the next day's New York Times. Court, 5-4, Votes To Restudy Rights in Minority Suits, N.Y. Times, Apr. 26, 1988, at 1, col. 6. The subtitle was "Extraordinary Action Could Lead to Retrenchment on Earlier Protections." According to Newsweek, "liberals on and off the court were aghast at their vision of a new conservative majority, created when Justice Anthony Kennedy joined the bench in February, running roughshod over legal precedents." Why Open a Closed Case? Upheaval on the Court, Newsweek, May 9, 1988, at 71. The New Republic commented that

[w] ith so many liberal doctrines now woven into "the fabric of our law," liberals like the idea that they should be preserved even if most justices think they are wrong. Conservatives complain that this notion turns the Supreme Court into a one-way legal ratchet: liberal majorities add new doctrines but conservative majorities can't subtract them. How much respect the Court should give its own past rulings is a perennial question that will be paramount in the coming years. Certainly, though, it represents an extreme approach for the Court to announce it has decided to reopen an old controversy when nobody has even asked it to do so.

"TRB," The Fifth Man, The New Republic, May 16, 1988, at 4, 42; see also Greenberg, Distressing Signals from the Court, N.Y. Times, May 18, 1988, at 31, col. 2; Neuborne, The Run on Runyon: Will Stare Decisis Become Bankrupt?, Legal Times, May 9, 1988, at 16. Concerns about the opinion are not, however, limited to liberals. Newsweek quotes a prominent conservative law professor as saying, "The decisions involved here haven't done any great damage to the legal system, and in fact, they may have done some good .... It seems a very academic exercise to say those cases are now questionable." Newsweek, supra.

4. 427 U.S. 160 (1976). Runyon involved racial discrimination by private schools. The lower 
nation by private parties as well as discrimination by state governments.

In practical terms, Runyon is only a moderately significant decision. With the notable exception of discrimination by private schools, most forms of discrimination that can be reached under Runyon can also be reached under other statutes. ${ }^{5}$ So it was not the potential practical impact of overruling Runyon that sparked public interest. Rather, it was the Justices' seeming willingness for the first time to overrule a civil rights precedent and thereby retreat from the Court's support for racial equality.

The reargument order was contested by two forceful dissents written by Justices Stevens and Blackmun, dissents which in turn led the five-member majority to issue a per curiam reply. The dissenters argued that the majority's action was unwarranted given both the failure of Congress to overrule Runyon and the longstanding public policy against racial discrimination.

The dissenting and majority opinions raise intriguing questions with implications which go far beyond the issues raised in litigation. My remarks will be directed primarily to these broader issues. Specifically, I will address three of the issues raised by Patterson and Runyon. Part I will consider the relevance of original intent to issues of statutory construction such as that involved in Runyon. Now that the Court has decided to revisit Runyon, should it consider only the original understanding 6 of section 1981, or should it also consider the current legislative consensus against racial discrimination? The Patterson dissenters found the fact that Congress has left Runyon intact an indication of that consensus. The majority apparently did not. Part II will therefore consider whether legislative silence is a relevant factor in applying stare decisis. Here, I will sometimes invoke economic meth-

courts had anticipated the Runyon holding. See C. ABERNATHY, CIVIL RIGHTS: CASES AND MATERIALS 265-76 (1980).

5. This overlap may present some problems in coordinating $\S 1981$ remedies with those provided by other statutes. See C. ABERNATHY, supra note 4, at 270-72; T. EISENBERG, CIVIL Rights Legislation: CASES AND MATERIALS $874-77$ (2d ed. 1987). These coordination problems are the major practical difficulty created by Runyon. Overruling Runyon would not, however, eliminate these problems because, like $\S 1981$, the other statutes also cover state governments.

6. There is currently a dispute about whether statutory interpretation should focus on the intent of the legislature or on the meaning of the statute to the reasonable reader of the time. For discussion of this issue and citations to opposing views, see Easterbrook, The Role of Original Intent in Statutory Construction, 11 HARV. J.L. \& PUB. POLY. 59 (1988); Farber \& Frickey, Legislative Intent and Public Choice, 74 VA. L. REv. 423, 452-61 (1988). This debate is not relevant to the issues discussed in this essay. My use of the phrase "original understanding" is deliberately ambiguous as to whether it is the understanding of the legislators or the citizenry that counts. 
odology, in the spirit of a recently developed approach to the study of political institutions known as public choice theory. ${ }^{7}$ I will not rely exclusively on this approach, nor do I claim that economic methodology is either descriptively or normatively complete as a method of analysis. Economic analysis can, however, be helpful in attempting to unravel some of the complexities of these problems. Finally, I will discuss whether considerations of public policy should play a greater role in deciding whether to overrule a precedent than in the initial decision on an issue of statutory construction. The dissenters viewed the national commitment against racial discrimination as relevant to the question of reopening Runyon. The majority retorted that this argument essentially gave civil rights litigants an unjustified advantage over other litigants. This dispute about the meaning of principled decisionmaking is the subject of Part III.

Each of these issues raises deep jurisprudential problems, and I make no pretense of offering a definitive treatment. I merely wish to identify those problems as a basis for continuing investigation and debate.

\section{ORiginal Understanding and Statutory CONSTRUCTION}

'The Runyon Court found little difficulty in construing section 1981 as reaching private conduct. Indeed, the Court found that this conclusion was already "well established" on the basis of prior decisions involving section $1981 .^{8}$ Runyon was also supported by the analogous holding regarding section 1982 in an open-housing case, Jones v. Alfred $H$. Mayer Co., ${ }^{9}$ which squarely held section 1982 applicable to private housing discrimination. The two concurring opinions in Runyon suggested that the Court's original construction of these two sections might have been unsound but that stare decisis barred reconsideration of that question. ${ }^{10}$

In his dissenting opinion in Runyon, Justice White argued that Jones was distinguishable because section 1981 had a different statutory origin. According to Justice White, section 1981, unlike section 1982, did not originate as part of the Civil Rights Act of 1866, though that statute contained very similar language. Rather, Justice White

7. The reader who is unfamiliar with public choice theory will find useful articles in Symposium on the Theory of Public Choice, 74 VA. L. REV. 167-518 (1988).

8. Runyon, 427 U.S. at 168.

9. 392 U.S. 409 (1968).

10. See 427 U.S. at 186 (Powell, J., concurring) ("The applicability of $\$ 1981$ to private contracts has been considered maturely and recently, and I do not feel free to disregard these precedents."); 427 U.S. at 189, 191 (Stevens, J., concurring) ("For the Court now to overrule Jones would be a significant step backwards ....".) (footnote omitted). 
traced section 1981 to an 1870 statute. The 1870 statute was based on the fourteenth amendment, unlike the 1866 Act, which was based on the thirteenth amendment. ${ }^{11}$ The fourteenth amendment roots of the 1870 statute at issue in Runyon, White argued, supported an interpretation requiring a finding of state action.

The Runyon majority did not contest Justice White's reading of the 1870 statute. Instead, the majority argued that the 1870 language and the 1866 language had coalesced into the current section, as part of an 1874 effort at codifying federal law. ${ }^{12}$ Thus, the correctness of Justice White's argument turned on the question whether in 1874, while attempting to codify prior law, Congress had repealed the relevant language from the 1866 Act and had reenacted the similar language from 1870. If the 1874 revision did not affect the portion of the 1866 Act considered in Jones, then Jones was distinguishable.

The strongest support for White's interpretation is the historical note to section 1981 accompanying the 1874 revision, which mentioned the 1870 statute but not the 1866 statute. But the limited authority of the revisers, which did not include the power to make substantive legal changes, undermines this support. The Runyon Court declined to "attribute to Congress an intent to repeal a major piece of Reconstruction legislation on the basis of an unexplained omission from the revisers' marginal notes."13

Because the majority's interpretation assumes that the 1866 statute applied to private conduct, the only question is whether the current statute derives from the 1866 or the 1870 enactment. But it is also possible to argue with considerable force that the Court's understanding of the 1866 statute was itself mistaken. ${ }^{14}$ Justice White, considering himself bound by the contrary holding regarding section 1982 in Jones, left this question unaddressed. Because the Patterson Court did not request argument about Jones and because none of the dissenting Justices seem to think the validity of Jones is in question, the Patterson order presumably does not reopen the Jones Court's interpretation of

11. 427 U.S. at 195-211 (White, J., dissenting). Justice White also relied on the language of the provision, 427 U.S. at 193-95, but to my mind the language is by no means unambiguous. Although Justice White's reading of the "right" to contract as a reference to discriminatory state laws is certainly plausible, it is not uncommon for the word "right" to be used in other ways. For example, if a private university were to refuse to hire someone because of that person's political views, it would not be at all odd for a critic to say that the individual had a "right" to be considered on the merits, without reference to political factors.

12. 427 U.S. at 168 n.8.

13. 427 U.S. at 169 n.8.

14. Some noted historical authorities have taken this position. The historical evidence is exhaustively reviewed in C. FAIRMAN, History of THE SUPREME COURT OF THE UNITED STATES: RECONSTRUCTION AND REUNION 1864-88, pt. 1, 1207-300 (1971). 
the 1866 statute. ${ }^{15}$ If the viability of Jones is not currently at issue, the argument for overruling Runyon turns solely upon Justice White's argument for distinguishing the two cases.

Whatever support for White's view that can be gleaned from the notes of the 1874 codification, the meager historical evidence concerning congressional motivation renders an interpretation of the historical record intrinsically uncertain. This raises an important issue regarding statutory interpretation: Where the evidence of the original understanding is unclear, must a judge pick the most probable interpretation of the evidence, or may the judge consider other factors as well? The question, in short, is whether statutory interpretation is strictly governed by originalism.

Some of the standard arguments made against originalism in constitutional law ${ }^{16}$ also apply in the statutory context, ${ }^{17}$ particularly where the statutory language is broad and the statute is old. As with constitutional provisions, determining the original understanding of an old statute may be more difficult because of gaps in the historical record, because of the divergent views of those involved in making the crucial legislative decisions, and because of changes in linguistic usage and cultural contexts. Moreover, as with constitutional provisions, the original understanding of a broadly worded statute can be defined at various levels of generality, leading to potentially different results. Thus, originalist analysis may be incapable of answering some fundamental questions, at which point recourse to some other interpretative approach is necessary. Hence, at least when originalism can provide no answer, recourse to nonoriginalist considerations seems clearly appropriate if not imperative.

There seems to be no escape from nonoriginalism when the original understanding is entirely indeterminate. ${ }^{18}$ For example, if we assigned equal probabilities to two opposing views of the historical record, we would necessarily have to turn to some alternative method

15. Also, the Patterson order specifically refers to $\$ 1981$, while Jones involved $\S 1982.108$ S. Ct. at 1420. This seems to be another indication that the validity of Jones is not currently in question.

16. For a survey of the literature, see D. Farber \& S. Sherry, A History of the American Constitution ch. 14 (forthcoming 1989).

17. The problem of originalism in statutory cases is closely linked with a deeper question about the appropriateness of formalism in the statutory area. Some important scholarship has begun to address this problem. See Posner, Legal Formalism, Legal Realism, and the Interpretation of Statutes and the Constitution, 37 CASE W. REs. L. REV. 179 (1986-1987); Weisberg, The Calabresian Judicial Artist: Statutes and the New Legal Process, 35 STAN. L. REv. 213, 232-37 (1983); Schauer, Formalism, 97 YALE L.J. 509 (1988).

18. In such cases, as Professor Tribe observes, the court must invoke some "background principle" to decide the case. See Tribe, Judicial Interpretation of Statutes: Three Axioms, 11 Harv. J.L. \& Pub. Poly. 51, 55 (1988). 
of interpretation. The result should not be radically different if we were then to locate a small shred of relevant historical evidence, so that instead of viewing the question as a 50-50 bet, we would now bet 51-49 in favor of the truth of one historical view. If we had powerful, nonoriginalist reasons for favoring the less probable interpretation when it was an even bet, we would be foolish to abandon that position based on a trivial piece of additional historical evidence. ${ }^{19}$ Indeed, basing interpretations solely on definitional probabilities while ignoring the other values at stake would violate accepted models for rational decisionmaking under conditions of uncertainty. 20

Like the hypothetical case of the 51-49 bet, Runyon was a relatively easy case for applying nonoriginalism, given Justice White's concession that the 1866 statute applied to private discriminatory acts. ${ }^{21}$ The only controversy remaining in the wake of this concession concerns the original understanding of the 1874 revision. And given the relatively thin historical record on that revision, recourse to nonoriginalist considerations was clearly appropriate. Furthermore, racial equality, as I will discuss later, is in this context as noncontroversial a consideration as one could hope to find. ${ }^{22}$ To put it more bluntly, it is dubious that the legality of discriminatory private schools today should turn on the marginal annotations of statutory revisers a century ago. Thus, the Runyon Court was on solid ground in rejecting White's meager historical evidence for his interpretation. Nevertheless, given the possibility that the present Court might not agree with this reading of section 1981 on the merits, it is also important to consider the bearing of stare decisis on Patterson. That is the subject of the next two sections.

19. An originalist might retort that judicial legitimacy in statutory cases derives entirely from the original intent of the legislature. Hence, any hint as to original intent must be followed without deviation. A full discussion of this argument would go beyond the scope of this essay, but I believe that a useful response could be shaped along Rawlsian lines. Behind the Rawlsian veil of ignorance, suppose that individuals do not know if they will turn out to be enacting legislators or judges construing legislation. What rules would they agree on as fair? Strict originalism seems a highly implausible answer.

20. See Farber \& Frickey, supra note 6, at 461-65.

21. When the original understanding seems clear, bringing current public values to bear becomes much more problematic. The question of statutory originalism also raises some difficult issues about how the courts can identify public values in areas of public controversy. For discussion of this problem, see Eskridge, Dynamic Statutory Interpretation, 135 U. PA. L. REV. 1479 (1987) [hereinafter Eskridge, Dynamic Interpretation]; Eskridge, Public Values in Statutory Interpretation (forthcoming) [hereinafter Eskridge, Public Values]; Farber \& Frickey, The Jurisprudence of Public Choice, 65 TeXas L. REV. 873, 909-11 (1987); Sunstein, Factions, SelfInterest, and the APA: Four Lessons Since 1946, 72 VA. L. REV. 271 (1986).

22. See text at notes $59-61$ infra. 


\section{Legislative Inaction and Stare Decisis}

In opposing reargument in Patterson, Justice Blackmun relied heavily on the doctrine that stare decisis applies with special force in matters of statutory interpretation. ${ }^{23}$ The Court's reading of a statute is thought to be particularly invulnerable when, as in Runyon itself, Congress has rejected attempts to reverse the Court's interpretation. Unimpressed, the Patterson majority noted that the Court has "explicitly overruled statutory precedents in a host of cases" and that stare decisis is a "principle of policy and not a mechanical formula."24 Thus, the majority's decision to rehear the case must reflect a view that congressional silence is not an absolute bar to reconsidering past opinions. But the majority did not address the question of whether congressional silence is entitled to significant weight in deciding stare decisis issues, and, of course, there was no reason for the majority to do so in the context of an order for reargument. The weight to be given congressional silence, then, remains an open issue, which will probably figure in the ultimate resolution of the case.

Patterson thus seems likely to occasion a continuation of the debate begun in Johnson v. Transportation Agency ${ }^{25}$ about the relevance of the "sounds of silence" to stare decisis issues. ${ }^{26}$ Johnson involved an affirmative action issue under Title VII of the 1964 Civil Rights Act. ${ }^{27}$ In dissent, Justice Scalia argued in favor of overruling a previous decision, ${ }^{28}$ which had allowed affirmative action under some circumstances. ${ }^{29}$ The majority responded that "Congress has not amended the statute to reject our construction, nor have any such amendments even been proposed, and we therefore may assume that our interpretation was correct." 30 Calling on the majority to abandon the "canard" of "vindication by congressional inaction," 31 Justice Scalia launched a

23. For background concerning this doctrine, see W. ESKRIDGE \& P. FRICKEY, CASES AND Materials on Legislation: Statutes and the Creation of Public Policy 303-07 (1988). An extensive discussion of the Court's previous application of this doctrine can be found in Eskridge, Overruling Statutory Precedents, 76 GEO. L. REV. 1361 (1988). A similar approach apparently prevails in Britain. See A. PATERson, The LAW LoRds 156-58 (1982).

24. $108 \mathrm{~S}$. Ct. at 1420-21 (citations omitted).

25. 107 S. Ct. 1442 (1987).

26. The musical allusion derives from Tribe, Toward a Syntax of the Unsaid: Construing the Sounds of Congressional and Constitutional Silence, 57 IND. L.J. 515 (1982). For background on the issue, see W. EsKRIDGE \& P. FRICKEY, supra note 23, at 307-22.

27. 42 U.S.C. $\S 2000 \mathrm{e}$ to $2000 \mathrm{e}-17$ (1982).

28. United Steelworkers, v. Weber, 443 U.S. 193 (1979).

29. Johnson, $107 \mathrm{~S}$. Ct. at 1473-74 (Scalia, J., dissenting).

30. $107 \mathrm{~S}$. Ct. at 1451, n.7.

31. $107 \mathrm{~S}$. Ct. at 1473. 
vigorous attack on the presumption that congressional silence constitutes approval of the Court's interpretation of a statute.

Justice Scalia's dissent in Johnson essentially makes two arguments. First, he argues that congressional failure to act will often be explained by factors other than approval of the Court's decision. Second, he suggests that the presumptions rest "on the patently false premise that the correctness of statutory construction is to be measured by what the current Congress desires, rather than by what the law as enacted meant." 32 Apart from whatever support from fellow Justices may be reflected in the Patterson reargument order, Justice Scalia's view is shared by Judge Frank Easterbrook and other scholars. ${ }^{33}$

The language used in statutory interpretation opinions is notoriously wooden. There may well be opinions treating congressional silence as a completely dispositive event, as if Congress had amended the law in line with the Court's decision. Against this mechanistic treatment of congressional silence, Justice Scalia's arguments are powerful. But it is doubtful that the Court has ever really embraced such a mechanical approach to the problem. The interesting question, in any event, is whether congressional silence should be given significant weight in considering stare decisis issues. On that point, Scalia's arguments are less convincing.

The first question Scalia raises is whether congressional silence is a valid indicator of congressional approval. As he points out, there are a number of reasons why Congress might fail to act even though a majority of its members disapprove of a judicial decision. Perhaps the most notable reason is the power of committees and party leaders to control the congressional agenda. ${ }^{34}$ For reasons also relating to agenda control, a shift in coalitions can also block measures to overturn a judicial interpretation, even though the statute would not have initially passed if the Court's later interpretation had been foreseen. ${ }^{35}$

32. $107 \mathrm{~S}$. Ct. at 1472-73. Justice Scalia made somewhat similar arguments in his dissent in United States v. Johnson, 107 S. Ct. 2063, 2075 (1987) (Scalia, J., dissenting).

33. See Easterbrook, Stability and Reliability in Judicial Decisions, 73 CORNELL L. REv. 422 (1988); Maltz, The Nature of Precedent, 65 N.C. L. REV. 367, 388-90 (1987); Posner, Economics, Politics and the Reading of Statutes and the Constitution, 49 U. CHI. L. REv. 263, 275 (1982); Rees, Cathedrals Without Walls: A View from the Outside (Book Review), 61 Texas L. REv. $347,373-78$ (1982) ("In cases where the judge's role is to apply and interpret laws that have been made by others, prior judicial opinions may contain highly persuasive arguments about what the laws mean, but they cannot relieve the judge of his obligation to decide.").

34. For a formal model developing this point, see Marks, A Model of Judicial Influence on Congressional Policymaking: Grove City College v. Bell (Feb. 23, 1988) (unpublished manuscript).

35. See Eskridge, Dynamic Interpretation, supra note 21, at 1524-25. 
Thus, Justice Scalia is on solid ground when he suggests that congressional silence can have many explanations. But of course, this is something that no one has questioned - including the majority in Johnson. ${ }^{36}$ Silence is an imperfect signal of congressional approval. Nevertheless, silence clearly communicates some information about congressional approval. Because Congress will virtually never ${ }^{37}$ vote to overturn an interpretation it agrees with, its failure to overturn the statute increases the likelihood that Congress in fact agreed. Indeed, so long as silence is a more likely response when Congress affirmatively approves of the Court's interpretation than otherwise, probability theory indicates that, no matter how many other causes of congressional silence may exist, silence is still a signal of congressional approval. This can be shown with a formal Bayesian analysis, but an example may be more instructive. Consider two urns, one of which (urn $A$ ) contains only white marbles, while the other (urn $B$ ) contains equal numbers of black or white marbles. A marble is randomly chosen from the two urns. It turns out to be white. Obviously, a white marble could have come from either urn. Nevertheless, two out of three times, the white marble will have come from urn $A$. (On the average, four drawings will produce two white marbles from urn $A$, a white marble from urn $B$, and a black marble from urn $B$. Thus, on the average, twice as many white marbles will turn out to have been drawn from urn $A$ as urn $B$.) So, even though the marble could have come from either urn, it is still a meaningful indicator of the identity of the urn. Similarly, although congressional silence could result from either congressional approval or other factors, it still increases the likelihood of congressional approval. It should, after all, be no surprise that evidence need not be completely reliable to be entitled to consideration.

The real question then is not whether congressional silence carries information, but how much information it carries. Clearly, the answer depends on our appraisal of the plausibility of other possible explanations for congressional silence. For example, in an area like civil procedure, to which Congress is quite inattentive, silence means little. ${ }^{38}$

36. See 107 S. Ct. at 1451 n.7.

37. One can imagine situations in which a powerful minority might be able to attach such a provision as a rider to a measure that the majority would then feel compelled to pass. Also, if the minority's preferences were intense and the majority's were weak, the majority might give way, perhaps as part of a log-rolling deal.

38. Perhaps this observation explains why the Court gave no thought to legislative silence in a recent case involving an arcane point of appellate practice, even though the result was to overturn a fifty-year-old interpretation of the governing statute. Gulfstream Aerospace Corp. v. Mayacamas Corp., 108 S. Ct. 1133, 1138-42 (1988). 
On the other hand, in a highly controversial area like affirmative action, the Johnson majority was surely correct in stressing that not a single member of Congress introduced legislation to overturn the Court's previous decision. ${ }^{39}$ Thus, although a careful appraisal of the circumstances is in order, it is neither logically impossible nor necessarily difficult in practice to infer approval from legislative inaction.

The harder question is whether congressional approval matters. The heart of Justice Scalia's argument is that any deviation from originalism is a betrayal of the original meaning of the measure. ${ }^{40}$ As Judge Easterbrook says with his customary clarity, "If courts become instruments by which packages are undone, laws will be harder to pass. Bargains must be kept to be believed, and inferences from legislative inaction are a means by which bargains are broken." 41 The assumption, then, is that the original supporters of a statute would prefer courts to enforce the "statutory bargain" even at the cost of overruling precedent.

This may well be true ex post (that is, viewing the matter after the fact). After the Court misconstrues a statute, some or all of its original supporters might well prefer that the Court give no weight to legislative silence or stare decisis itself. But, as Judge Easterbrook has suggested in another context, ex post analysis is often inappropriate because it ignores the prospective effects of legal decisions. ${ }^{42}$ The proper analysis here is ex ante. In other words, we must ask what rule about legislative inaction would be preferred by the majority coalition at the time of the original enactment.

One problem with Scalia's analysis is that it overestimates the importance to legislators of having courts correct mistaken judicial interpretations of statutes. Significant reasons exist for doubting that legislators put absolute priority on ultimately obtaining correct inter-

39. See $107 \mathrm{~S}$. Ct. at 1450 n.7. Professor Eskridge argues that the failure of Congress to respond to Weber may simply have been an indication that the groups benefitting from the decision were much better organized while the victims were amorphous and lacking in political clout. Eskridge, supra note 23, at 1410-11. This explanation seems implausible, for while it might well account for the failure of Congress actually to legislate in the area, it does not account for the failure of any member of Congress even to introduce a bill on the subject. It is not as if ideological opponents of affirmative action were unrepresented in Congress in the years preceding Johnson.

40. A quite different argument can also be made, which is that legislators are so bad at formulating policy that courts should pay as little attention to them as possible. While a full discussion of this point would take me far afield, I must say that I am not yet persuaded to place such a low value on democratic institutions.

41. Easterbrook, supra note 33 , at 429 . The idea of viewing statutes as legislative deals originated in Landes \& Posner, The Independent Judiciary in an Interest-Group Perspective, 18 J.L. \& ECON. 875 (1975).

42. This is a major theme of Easterbrook, The Supreme Court, 1983 Term - Foreword: The Court and the Economic System, 98 HARV. L. REv. 4 (1984). 
pretations. At the time of enactment, members of the winning coalition have no way of knowing whether judicial mistakes will favor them (giving them more than the original "bargain") or injure them (giving them less than they bargained for). Provided courts make a good-faith effort to interpret statutes correctly, legislators can expect both kinds of mistakes to happen with equal likelihood, ${ }^{43}$ so the expected cost of incorrect decisions as such is zero. ${ }^{44}$ At this level of analysis, legislators are ex ante indifferent to judicial mistakes because they can expect the errors to balance out.

Thus, from an ex ante perspective, judicial errors are a less serious concern to legislators than they would appear to be after the fact. Legislators do have some reasons to be concerned about prospective uncertainty in judicial interpretations. If the enacting legislators are risk-averse, they may have some reluctance to gamble on the direction of judicial error. There also may be social costs, such as increased litigation and difficulty in planning transactions, associated with uncertainty about how statutes will be construed. 'Jettisoning stare decisis would do relatively little to reduce these various uncertainty costs. ${ }^{45}$ On the other hand, a rule allowing ready judicial correction of prior mistaken opinions creates a variety of social costs. ${ }^{46}$ In general, then, enacting legislators would prefer that courts give strong weight

43. This point may require some explanation. After all, legislators might perceive that judges are hostile to certain types of legislation and will therefore construe the legislation narrowly. Thus, they may anticipate that courts will be biased against enforcement (or, for that matter, in the opposite direction). But rational legislators, knowing this, will normally draft the statute more expansively so as to counter the judicial bias. Provided judges are making a goodfaith (even if biased) attempt to interpret statutes, they will be responsive to sufficiently strong statutory language.

44. Even if legislators do expect judges to be systematically biased but cannot for whatever reason compensate for the bias when drafting statutes, they have little reason to favor weakening stare decisis rules. If judges are biased in interpreting statutes the first time around, the same biases will enter into both their decisions about which issues to rehear and their ultimate decisions after rehearing. Having a biased tribunal hear the same case twice is not a cure for bias.

45. If courts entirely ignore precedent and treat all statutory interpretation issues as open, decisions overruling prior precedents will be about as likely to be wrong as the earlier precedents themselves. Unrestrained overruling therefore creates no assurance that courts will ultimately settle on the correct interpretation of a statute. If courts overrule precedents only when there are strong reasons to believe that the early precedents were wrong, they can increase the chances that in the long run statutes will be correctly interpreted. Legislators should regard this as a desirable effect, although the magnitude of the benefits will be decreased because of the necessity of discounting such long-range consequences to present value. Legislators would then have to consider the trade-offs between this increase in long-run reliability and the costs associated with decreased legal stability. I suspect that the Court's current application of stare decisis is not far from the rational legislator's preferred rule.

46. These social costs are simply the flip side of the policies favoring stare decisis, which are discussed in Monaghan, Stare Decisis and Constitutional Adjudication, 88 Colum. L. REv. 723, 744-53 (1988); Monaghan, Taking Supreme Court Opinions Seriously, 39 MD. L. REv. 1, 3-10 (1979); Posner, The Constitution as an Economic Document, 56 GEO. WASH. L. REV. 4, 33-37 (1987); Schauer, Precedent, 39 STAN. L. REv. 571, 595-602 (1987). Among the social costs are the delay and expense of additional litigation, the increased difficulty of transactional planning, a 
to stare decisis in statutory cases, even at the expense of fidelity to the original legislative deal.

This analysis suggests that legislators' initial stake in having a statute correctly interpreted is largely dissipated in the "first round" when the courts give an initial authoritative interpretation. In the second round, when the question is whether to correct an initial mistake, the enacting legislator's main interest is in minimizing social costs. In other words, the interest of the enacting legislature largely coincides with that of society as a whole at the time of the second decision. From this perspective, the Court's initial violation of the original understanding is to some extent a "sunk cost" which is no longer relevant.

Like the citizenry at large, enacting legislators would also ex ante prefer courts to give weight to future congressional approval in applying stare decisis. The reason is that ignoring changing congressional attitudes is itself costly. If a later Congress actually approves of the Court's original interpretation, an overruling would create several kinds of additional social costs. First, congressional disapproval of the overruling means that legislative resources will be devoted to considering the advisability of further legislation. Apart from their monetary costs, these hearings and debates carry an opportunity cost in terms of Congress' ability to address other issues. The further the amendment gets in the legislative process, the higher the costs will be; in general, we can expect more extensive congressional activity when Congress strongly disapproves of the result. Second, whether or not new legislation actually results, Congress' disapproval of the overruling creates the risk of an amendment. Thus, the Scalia approach creates two kinds of uncertainty: First, since judicial decisions of which Congress approves are more likely to be overruled under his approach, the level of legal uncertainty is increased prior to any actual overruling (even when ultimately no overruling results). Second, after the overruling, uncertainty will remain high because of the prospect of congressional action. In short, a willingness to overrule decisions even when Congress approves of them entails heightened social costs. Ex ante, legislators would prefer a stare decisis rule that lowers those costs.

The precedential force to be given statutory precedents is a compli-

general reduction in private compliance with current legal doctrines, and the increased difficulty in drafting new legislation against an uncertain legal background.

It might be thought that making judicial decisions prospective would eliminate these costs, but the possibility of a prospective ruling is still a source of uncertainty. Moreover, if statutory interpretations were normally prospective, the practical effect would be to delay the implementation of statutes. This would decrease a statute's discounted present value to the enacting legislature, so legislators would generally reject such a rule. 
cated question. The fundamental problem is that of trading off the desirability of improved interpretations of statutes against the various social costs of legal instability. My purpose here has been the modest one of establishing that congressional approval of a precedent ought to weigh in its favor, and that silence can be a signal of approval. The widely varying settings of cases make it hard to assess in advance just how reliably silence signals approval or just how much approval should count in the balance. The Patterson setting, however, is unusually suggestive of actual approval, and further congressional action is a realistic likelihood if the Court overrules Runyon. ${ }^{47}$ So, subsequent congressional silence deserves substantial weight in Patterson.

\section{The Problem of Neutral Principles}

Perhaps the most interesting aspect of the Patterson order relates to the conflicting visions of the majority and dissenters about the meaning of principled adjudication. Both dissents emphasize that the majority's decision is especially unfortunate because the subject is racial equality. Justice Blackmun's dissent says that he is "at a loss to understand the motivation of five Members of this Court to reconsider an interpretation of a civil rights statute that so clearly reflects our society's earnest commitment to ending racial discrimination . . .."48 Justice Stevens, in turn, laments the effect of the order on "the faith reposed by racial minorities" in the Court's commitment to racial justice. ${ }^{49}$

In response, the majority argues that the dissenters were seeking special advantages for a particular class of litigants, in violation of the rule of law:

Both of the dissents intimate that the statutory question involved in

Runyon v. McCrary should not be subject to the same principles of stare decisis as other decisions because it benefited civil rights plaintiffs by expanding liability under the statute. We do not believe that the Court may recognize any such exception to the abiding rule that it treat all litigants equally: that is, that the claim of any litigant for the application of a rule to its case should not be influenced by the Court's view of the worthiness of the litigant in terms of extralegal criteria. We think this is what Congress meant when it required each Justice or judge of the United States to swear to "administer justice without respect to persons,

47. Congress has several times amended the civil rights statutes to override restrictive Supreme Court interpretations. See 42 U.S.C. $\$ 2000$ e(k) (1982) (overturning General Electric v. Gilbert, 429 U.S. 125 (1976)); 42 U.S.C. $\$ 1973$ (1982) (overturning Mobile v. Bolden, 446 U.S. 55 (1980)); and most recently, the Civil Rights Restoration Act of 1987, Pub.L. No. 100259, 102 Stat. 28 (1988) (overturning Grove City College v. Bell, 465 U.S. 555 (1984)).

48. $108 \mathrm{~S}$. Ct. at 1422.

49. $108 \mathrm{~S}$. Ct. at 1423. 
and do equal right to the poor and to the rich . . .."50

This passage seems to resurrect the debate that was sparked almost thirty years ago by Herbert Wechsler's classic article on "neutral principles."s1

One view of neutral principles, which was stressed by Wechsler, emphasizes the importance of judicial candor. ${ }^{52}$ Judges should only be influenced by considerations that they are willing to explain in their opinions and that they are willing to apply in future cases as well. ${ }^{53}$ In this sense, judicial opinions should be "transparent" in revealing the motivation behind the decision. Although it is possible to imagine cases in which transparency arguably might not be appropriate, ${ }^{54}$ it is obviously an important virtue.

There is little reason to doubt the dissenters' adherence to this principle of judicial candor. The dissenters cannot be accused of violating the transparency principle, since they are quite explicit about the basis of their views. They make it clear that they give substantial weight to the fact that Runyon favors the cause of racial equality. Their real quarrel with the majority is whether this factor is legally relevant. If, as they believe, it is legally relevant, they cannot be accused of violating any norm of judicial neutrality.

Once the misleading references to the rule of law are cleared away, there remains a significant disagreement between the majority and dissent about the criteria relevant to the decision to overrule. The dis-

50. 108 S. Ct. at 1421 (quoting 28 U.S.C. $\$ 453$ (1982)). On one reading, the majority's position is clearly correct but beside the point. It is very nearly a tautology to say that the Court should not be influenced by "extralegal criteria." A criterion that can rightfully influence a judge might very well be termed a "legal criterion" as a matter of definition. On this reading, the majority's position is that a court should only be influenced by those factors it should be rightfully influenced by. Although this proposition is clearly true, it seems reasonable to assume that the majority had something more in mind.

51. Wechsler, Toward Neutral Principles of Constitutional Law, 73 HARV. L. REv. 1 (1959).

52. See id. at 19-20, 25-26, 33. For an insightful recent discussion of the importance of transparency, see Shapiro, In Defense of Judicial Candor, 100 HARV. L. REv. 731 (1987). One of Alexander Bickel's major criticisms of the Warren Court was that the Court often decided cases on the basis of arguments that in reality the Court would not have been willing to apply more generally; those arguments consequently could not have been the true basis for decision. See A. BiCKel, The Supreme Court and the Idea of Progress 44-100 (1970). But Bickel clearly did not believe that making value judgments was necessarily inconsistent with the judicial role. See, e.g., id. at 77. This concern with transparency is even more evident in A. BICKEL, THE Least Dangerous Branch (1962).

53. For a more jurisprudential discussion of this point, see $\dot{\mathrm{L}}$. Fuller, THE Morality of LAw 81-83 (1964). As Fuller's discussion shows, the problem of transparency is linked with that of generality, because failures of transparency are often linked with spurious attempts to justify decisions by appealing to principles that do not in reality form the basis of the decisions. If judges did not attempt to give reasoned justifications for their decisions, the problem of transparency would not arise.

54. See Greenawalt, The Enduring Significance of Neutral Principles, 78 COLUM. L. REv. 982, 1006-13 (1978). 
senters believe that it is relevant that a past decision advanced an important social goal such as racial equality. The majority apparently believes that the Court's view of the societal value of a decision is irrelevant. For the majority, overruling a past decision that outlawed racial discrimination is neither more nor less desirable than overruling a past decision concerning price discrimination under the Robinson-Patman Act.

The extent to which judges can properly make value judgments involves deep questions going well beyond the scope of this comment. My own view is that judges not only can but must make value judgments in hard cases. This apparently was also the view of Professor Wechsler, and is probably that of most legal scholars, as Professor Kent Greenawalt has explained:

Wechsler does not contend that judges can decide constitutional cases without weighing conflicting values. He explicitly recognizes that judges must often make difficult choices among values and he does not suggest that the judge can somehow be neutral among those values.

Some scholars believe that in a deeper sense judges are supposed to be neutral among constitutional values, neutral in giving the weight to each value that is determined by the Constitution itself or some broader set of legal materials. ... [M] ost modern scholars would be skeptical of the claim that the ideal judge could always manage without relying on his own value judgments about right social behavior, and Wechsler advances no such thesis for sitting judges. ${ }^{55}$

In particular, Wechsler said in later correspondence that " $[\mathrm{b}] \mathrm{y}$ no possible reading did I say that the Supreme Court should have cast out of its reckoning the likelihood that a decision one way or another would effect 'an enduring contribution to the quality of our society." "56

Attempts by judges to rely on public values raise some obvious and troubling questions. ${ }^{57}$ The ability of judges to identify enduring values may well be questioned. Moreover, the results in many cases may be tightly constrained in ways that make reference to broader social values problematic. In general, judicial reliance on public values becomes more troublesome when the judge's value judgments are highly controversial and when the applicable legal rules refer to a very narrow range of relevant considerations. ${ }^{58}$ For example, it is dubious that the

55. Id. at $991-92$ (footnotes omitted).

56. Id. at 1012 n.92 (quoting letter from H. Wechsler to L. Pollak (Apr. 9, 1962) cited in Pollak, Constitutional Adjudication: Relative or Absolute Neutrality, 11 J. PUB. L. 48, 60-61 (1962)).

57. Some of these problems are explored in Eskridge, Public Values, supra note 21.

58. Even when a decision is highly discretionary, the range of factors relevant to that decision may be limited in ways that preclude consideration of certain policies. For example, allowing considerations relating to the merits of a case to enter into procedural decisions may well be improper (and covertly doing so is even more questionable). See Gunther, The Subtle Vices of 
application of a jurisdictional time limit should depend on the importance of the public policies involved in the merits of the case. These difficulties in determining the proper scope of public values in judicial decisions suggest that judges should be cautious in their reliance on such values.

Patterson is an easy case in at least one respect. If public values are relevant at all to the application of stare decisis, the values involved in Patterson are both powerful and noncontroversial. 59 There is much dispute in our society about how the norm of racial equality should be applied in connection with issues such as affirmative action. But the core equality norm - that intentional discrimination ${ }^{60}$ against racial minorities is impermissible - is surely not in dispute. ${ }^{61}$

Thus, if public values are ever appropriate considerations in deciding whether to reopen an issue, Patterson is such a case. The more interesting issue is whether it actually is appropriate to consider public values when deciding whether to overrule a prior decision. The Patterson majority apparently assumed the contrary, but there are substantial arguments for allowing consideration of public values.

Rather than being a domain of tightly constraining rules that preclude consideration of broader public values, stare decisis is a largely prudential doctrine. ${ }^{62}$ In applying the doctrine, courts have looked to

the "Passive Virtues"- $A$ Comment on Principle and Expediency in Judicial Review, 64 ColuM. L. REV. 1, 10-22 (1964). But the range of factors traditionally considered relevant to stare decisis is sufficiently broad not to preclude consideration of the potential social effects of an overruling.

59. The Patterson majority's unwillingness to consider this public value is disheartening. Perhaps the majority's view is that judges in their official capacity should be neutral about values like racial equality. Such a conception of the judicial role would be not only profoundly formalistic, but an abandonment of an important part of the Court's institutional role.

60. Section 1981 only applies to intentional discrimination. General Bldg. Contractors Assn. v. Pennsylvania, 458 U.S. 375 (1982).

61. Indeed, the Court has expressly identified this norm as a general public policy applicable in matters of statutory construction. In a case that is particularly relevant to Runyon because of its subject matter, the Court denied tax exemptions to discriminatory private schools based squarely on the Court's determination of public policy. "There can no longer be any doubt," the Court said, "that racial discrimination in education violates deeply and widely accepted views of elementary justice." Bob Jones Univ. v. United States, 461 U.S. 574, 592 (1983). After reviewing legislative and executive action regarding racial discrimination, the Court concluded that "[w] hatever may be the rationale for such private schools" policies, and however sincere the rationale may be, racial discrimination in education is contrary to public policy." $461 \mathrm{U} . \mathrm{S}$. at 595. Justice Powell's concurrence contains a particularly good statement of the exceptional status of this public policy. See 461 U.S. at 606, 607 (Powell, J., concurring in part). The Court's willingness to rely on this public policy in Bob Jones was especially striking because doing so required considerable stretching of the statutory language.

62. Our history does not impose any rigid formula to constrain the Court in the disposition of cases. Rather, its lesson is that every successful proponent of overruling precedent has borne the heavy burden of persuading the Court that changes in society or in the law dictate that the values served by stare decisis yield in favor of a greater objective.

Vasquez v. Hillery, 474 U.S. 254, 266 (1986). 
a wide variety of considerations. These considerations include the extent to which the prior decision was poorly reasoned or contrary to prior precedent, the extent of public reliance on the prior decision, and the degree of difficulty encountered in attempting to apply the previous decision. ${ }^{63}$ In making other prudential decisions, such as determining whether an injunction is an appropriate remedy, judges often explicitly refer to the public interest. It is not surprising that some leading judges, including Justice Cardozo, have found it appropriate to consider the public interest in applying stare decisis. ${ }^{64}$

In defense of the majority opinion, it could be argued that public values are relevant, if at all, to the merits of the statutory issue, rather than to the stare decisis question. ${ }^{65}$ This argument overlooks an important part of the policy behind stare decisis. Stare decisis is important not only because actually overruling decisions imposes social costs, but because the prospect of potential overruling itself is a source of uncertainty and social costs. ${ }^{66}$ The traditional view, at least, is that these instability costs are quite large, which is why overrulings are exceptional. If we can identify areas in which instability costs seem particularly high, we should set the threshold for reconsideration higher in these areas. ${ }^{67}$ Although we cannot quantify the costs, it is reasonable to suppose that instability is particularly costly where major social values are threatened. ${ }^{68}$ If it is correct that instability costs are particularly high in cases involving major social values, ${ }^{69}$ overrul-

63. The "art of overruling" is insightfully discussed in Frickey, Stare Decisis in Constitutional Law: Reconsidering National League of Cities, 2 CONST. COMMENTARY 123 (1985).

64. See B. Cardozo, The Nature of the Judicial Process 149-52 (1921). For further discussion of this issue, see Monaghan, Stare Decisis and Constitutional Adjudication, supra note 46, at 760-62.

65. Along these lines, it could be argued that considering public values both as an independent factor in applying stare decisis and in connection with the underlying claim is a form of double counting. Alternatively, if public values are not relevant to the merits, why should they count at all in deciding whether to correct a mistake?

66. Compliance with decisions will be reduced by the possibility of an overruling. Also, lawyers will change litigation strategies in ways that may be costly. Most obviously, they will litigate whether to overrule cases more often if stare decisis is weak; they will also hedge against an overruling by attempting to find additional bases for legal claims. law.

67. This is the conventional reason for according unusual weight to stare decisis in property

68. Two reasons can be suggested for this conclusion. First, citizens are more likely to have firm expectations under rules that seem uncontroversial. Disappointing these expectations therefore creates a greater shock. Second, important social values may also be related to risk aversion. We often place a high social value on interests that are also of crucial importance to the individuals involved. Moreover, the risks of being deprived of these interests are also hard to avoid by diversification. Racial discrimination fits both models: it has a major impact on individual wellbeing, and the members of a racial minority are hardly in a position to diversify their "racial portfolios."

69. Since $\S 1981$ largely duplicates other statutes, it might be argued that overruling $R$ unyon would not threaten the major social value in racial equality. Two points can be made in re- 
ings should be made correspondingly more difficult. ${ }^{70}$

Another perspective on this problem emerges from combining Parts I and II of this article. In Part I, we saw that statutory construction often involves both the original understanding and considerations of current public policy. In Part II, we saw that the force of the original understanding is partially dissipated when the Supreme Court first interprets a statute. Public choice theory would suggest that when the question is whether to overrule an initial judicial "mistake," even the enacting legislators would often put a lower priority on the importance of enforcing the original understanding. This necessarily means that other considerations, such as enforcing current public policy, should play a greater role in the "second round."

Like the other issues raised by the Patterson rehearing order, the "public values" question raises deeper jurisprudential issues, which I have not attempted to address. At heart, the issue is the extent to which legal texts gain their meaning and authority from the circumstances of their making, and the extent to which their authority derives instead from their current place in the fabric of law and their current usefulness to society. Even the limited light shed by the analysis presented here, however, is in my view enough to show the complexities and difficulty of the position which the Patterson majority seems to have rather impulsively adopted.

Given the Supreme Court's unique role in the area of racial equality, it seems unfortunate that the Patterson Court picked a civil rights case in which to probe the limits of stare decisis. In any event, from the perspective of those who value stability in the law, the Patterson order is somewhat disturbing. In his concurring opinion in Runyon, Justice Powell said that the dissent's arguments were "quite persuasive" but that the argument "comes too late."71 If the argument was too late when Powell wrote in 1976, it surely is far too late twelve years later. The kinds of criticisms that can be levelled against Runyon can be made against many statutory construction decisions; we may be in for a rough ride if the Court means to revisit every statutory opinion in which the dissent had a cogent argument.

sponse. First, overruling Runyon could have a substantial effect in the not insignificant area of education. Second, per se rules may be useful in reducing uncertainty costs. A per se rule disfavoring overrulings in civil rights cases may be useful even if it does not fit every case.

70. The possibility that major rulings extending the scope of legal rights may be difficult to overturn may be a reason for caution in making such rulings in the first place.

71. Runyon, 427 U.S. at 186. 